FOLIA POMERANAE UNIVERSITATIS TECHNOLOGIAE STETINENSIS

Folia Pomer. Univ. Technol. Stetin., Oeconomica 2017, 337(88)3, 23-30

Wojciech LEWICKI

\title{
WSKAŹNIK TOTAL COST OF OWNERSHIP JAKO NARZĘDZIE SŁUŻACE OPTYMALIZACJI PROCESU ZAKUPOWEGO SAMOCHODÓW OSOBOWYCH
}

\author{
INDEX TOTAL COST OF OWNERSHIP AS THE TOOL SERVING \\ OF THE PURCHASE PROCESS OF PASSENGER CARS
}

Zakład Polityki Gospodarczej i Turystyki, Zachodniopomorski Uniwersytet Technologiczny w Szczecinie ul. Żołnierska 47, 71-210 Szczecin. adres e-mail: Wojciech.Lewicki@zut.edu.pl

\begin{abstract}
Summary. In the article an attempt to keep an eye on the being was made at using the TCO indicator, i.e. the total cost of ownership, as the tool serving the optimization of purchase processes on the example of selected passenger cars from the chosen market section. For empirical purposes they used the case study - with numerical experiment consisting in the TCO application in order to perform the comparative analysis of buying prices towards overall costs of using the vehicle after 3 summer period of his use. The whole of deliberations was supplemented for discussing the being of the TCO parameter in the process of the use of the vehicle. Signaling desired perspective directions of changes in processes of using to TCO is planning the article in defining the future purchase strategy both in the case of private users as well as owners of fleets of vehicles in Poland.
\end{abstract}

Słowa kluczowe: analiza kosztów, ogólny koszt posiadania pojazdu, koszty eksploatacji pojazdu, strategia zakupowa, rynek motoryzacyjny, decyzja dotycząca wydatków, wartość rezydualna.

Key words: cost analysis, overall cost of having a vehicle, operating cost of the vehicle, purchase strategy, automotive market, spending decision, residual value.

\section{WSTĘP}

Obserwacje rzeczywistości rynkowej wskazują, że w dobie stagnacji gospodarczej w wielu segmentach rynkowych zakup samochodu powinien opierać się przede wszystkim na precyzyjnym i realistycznym rachunku ekonomicznym. W praktyce oznacza to, że wszelkie wydatki na samochód należy kalkulować na podstawie wszystkich kosztów, jakie się z tym wiążą. Jak wskazują dostępne raporty i opracowania, wiele osób przy wyborze samochodu koncentruje się w pierwszej kolejności na cenie zakupu (Sołtysiak 2015), nie dokonując analizy kosztów związanych z jego eksploatacją. Zatem znajomość istoty parametru Total Cost of Ownership (TCO), czyli całkowitych kosztów użytkowania pojazdu, nabiera fundamentalnego znaczenia ekonomicznego zarówno dla użytkowników prywatnych, jak i właścicieli powiększającej się z roku na rok floty pojazdów użytkowych (Al-Alawi 2013).

W dostępnym piśmiennictwie z zakresu nauk ekonomicznych coraz częściej podkreśla się, że parametr TCO może mieć wpływ na zachowania nabywcze samych konsumentów (Daum 2011). Jak wiadomo, znajomość ceny zakupu prowadzić może do zoptymalizowania 
procesu zakupowego czy zdefiniowania danej strategii zakupowej zarówno w przypadku klientów indywidualnych, jak i flot (Schwan 2009).

Zatem w kontekście zniesienia wszelkich barier, dotyczących importu samochodów z krajów Unii Europejskiej oraz zmniejszenia stawek celnych na import spoza Unii Europejskiej, zagadnienie wykorzystania TCO jako narzędzia służącego optymalizacji procesu zakupowego, w odniesieniu do rynku motoryzacyjnego, stanowi istotny problem badawczy, tym bardziej że w dostępnym piśmiennictwie brakuje takowych analiz i opracowań, co jeszcze bardziej uzasadnia słuszność i zasadność podjęcia tej tematyki badawczej.

Zaprezentowane podejście stało się podstawą do przyjęcia warunków brzegowych i metodyki postępowania nakierowanej na próbę zwymiarowania parametru Total Cost of Ownership jako narzędzia służącego optymalizacji procesu zakupowego poprzez:

- zaprezentowanie istoty parametru TCO w procesie eksploatacji pojazdu;

- próbę wykorzystania parametru TCO do analizy i optymalizacji procesu zakupowego danego pojazdu z jednego segmentu rynkowego cieszącego się największą popularnością na polskim rynku.

Zasadniczym celem artykułu jest podkreślenie znaczenia wykorzystania TCO w procesach definiowania strategii zakupowej zarówno w przypadku użytkowników prywatnych, jak i flot pojazdów w Polsce.

\section{ISTOTA PARAMETRU TCO (CAŁKOWITY KOSZT POSIADANIA POJAZDU)}

Jak wskazuje dostępne piśmiennictwo z zakresu nauk ekonomicznych, Total Cost of Ownership (TCO) to termin służący określeniu struktury kosztów związanych z funkcjonowaniem aktywów w danym przedsiębiorstwie (Rogowski 2004). Na tym etapie rozważań warto podkreślić, że parametr ten jest także stosowany w odniesieniu do rynku motoryzacyjnego i definiowany jako całkowity koszt użytkowania pojazdu (Ellram 1995).

Zakup nowego samochodu to inwestycja o długoterminowych konsekwencjach ekonomicznych. Zatem każdemu użytkownikowi pojazdu powinno zależeć na oszacowaniu wszystkich kosztów związanych z jego posiadaniem. Takim narzędziem, pomocnym w tym procesie, może być wskaźnik TCO. Indeks te pozwala użytkownikowi pojazdu nie tylko na określenie kosztów, jakie będzie musiał ponieść podczas eksploatacji, ale także pozwala (już na etapie podejmowania decyzji o zakupie) określić, jaka będzie utrata wartości rynkowej po danym okresie jego użytkowania.

Jak wskazuje dostępna literatura przedmiotu, na TCO składają się dwa zasadnicze parametry: utrata wartości samochodu przy odsprzedaży oraz koszty jego użytkowania (Trömner 2014). Utrata wartości samochodu określana jest jako różnica między ceną zakupu samochodu a jego wartością rezydualną, czyli ceną odsprzedaży samochodu po okresie użytkowania. W dostępnym piśmiennictwie z zakresu nauk ekonomicznych mianem wartości rezydualnej określa wartość rynkową pojazdu w chwili odsprzedaży (Womack 2014). Wpływ na wartość rezydualną pojazdu ma wiele czynników natury technicznej. Większość z nich nie jest identyfikowana literaturze z zakresu nauk ekonomicznych. Ponieważ przy prognozowaniu przyszłej wartości pojazdu znaczenia nabiera np. cykl jego życia, czyli częstotliwość zmian modelu, korekt wyglądu (facelifting) i konstrukcji. Ponadto istotny wpływ na utratę wartości 
rezydualnej pojazdu ma jego wyposażenie, czyli im wyższy jest pakiet wyposażenia ponadstandardowego, tym mniejsza jest wartość rezydualna samochodu (Al-Alawi 2013).

Natomiast do kategorii kosztów użytkowania zalicza się m.in. koszt zużycia paliwa. Eksperci z rynku motoryzacyjnego podkreślają, że to jeden z trudniejszych do oszacowania elementów TCO, głównie ze względu na niewiadomą, jaką są ceny paliwa w dłuższej perspektywie czasu (Burnewicz 2005). Ponieważ na współczesnym rynku cena tego surowca zależna jest od wielu czynników, na które użytkownik pojazdu nie ma żadnego wpływu. Zdecydowanie łatwiejsze jest szacowanie wielkości spalania na podstawie analizy średniego przebiegu pojazdu. Ponadto w przypadku tej kategorii kosztów obserwacje rzeczywistości rynkowej wskazują, że należy polegać nie na danych katalogowych, a na rzetelnych testach spalania renomowanych instytutów badawczych.

Do kosztów użytkowania pojazdu zalicza się także koszty ubezpieczenia. Oszacowanie kosztów ubezpieczenia w pierwszym roku posiadania pojazdu nie jest procesem złożonym, natomiast już w kolejnych latach może być znacznie utrudnione, gdyż wielkość składki zależna jest od wielu zmiennych. Na tym etapie rozważań warto podkreślić, że na koszty ubezpieczenia wpływ ma nie tylko historia szkodowości, ale również wybrana marka, model czy wersja silnika. Nieco prostsze jest szacowanie kosztów ubezpieczenia w przypadku pojazdu leasingowego czy długookresowego wynajmu. W tym wypadku cena polisy jest składową płaconych rat i z reguły jest to stała wartość określona najczęściej na cały czas umowy.

Kolejne kategorie kosztów stanowią serwis i eksploatacja. Oszacowanie kosztów obowiązkowych przeglądów nie powinno przysporzyć problemów, ponieważ informacja o cenie za usługę i częstotliwości przeglądów dostępna jest u każdego dealera danej marki pojazdu. Natomiast znacznie trudniejszym procesem jest szacowanie kosztów ewentualnych napraw i kosztów części zamiennych. Autor uważa, że w przypadku tej kategorii kosztów warto przy podejmowaniu decyzji zakupowych przeanalizować w pierwszej kolejności dostępne rankingi usterkowości, na drugim etapie ocenić dostępność rynkową poszczególnych kategorii części zamiennych (Rozporządzenie Rady Ministrów z 8 października 2010).

Do kosztów użytkowania zalicza się także koszty zakupu opon oraz rejestracji. Choć koszty zakupu opon, jak wskazuje piśmiennictwo z zakresu ekonomiki transportu, stanowią część kosztów serwisowych (Kożlak 2010), to jednak, ze względu na cykliczność ich występowania, łatwiej jest oszacować ich koszt w dłuższym okresie w osobnej kategorii kosztów. Natomiast oszacowanie kosztów rejestracji nie powinno przysporzyć większych problemów, gdyż opłaty za rejestrację pojazdu nie uległy zmianie w ciągu kilku ostatnich lat.

$\mathrm{Na}$ tym etapie rozważań warto podkreślić, w przypadku TCO część ekspertów rynku motoryzacyjnego wspomina jeszcze o tzw. pozostałych kosztach posiadania auta. Do tej kategorii kosztów zalicza się opłaty parkingowe, za przejazd autostradami, koszty mycia pojazdu etc. Ponieważ ich udział w całkowitych kosztach użytkowania jest nieznaczny, większość analityków rynkowych nie uwzględnia ich w analizie TCO (Trömner 2014).

Obserwacje wskazują, że pomimo wielu zalet, wynikających z uwzględnienia w strategii zakupowej parametru w postaci całkowitych kosztów, narzędzie to nie jest stosowane. Wpływ na to ma kilka czynników, między innymi brak wiedzy dotyczącej możliwości zastosowania analizy TCO czy niewłaściwe procesowe podejście w realizacji potrzeb zakupowych. Analiza decyzji zakupowych na polskim rynku motoryzacyjnym wskazuje najważniejsze czynniki: 
- brak innych parametrów poza ceną zakupu. Parametr ceny zakupu pojazdu stanowi wciąż podstawowe kryterium wyboru. Wielu potencjalnych użytkowników wciąż decyduje się na zakup pojazdu, analizując wyłącznie cenę jego zakupu. Wskazuje to na brak świadomości, że w ogólnym rozrachunku potencjalne korzyści ekonomiczne uzyskane z powodu niskiej ceny zakupu pojazdu mogą zostać zniwelowane właśnie przez dodatkowe koszty związane z jego użytkowaniem;

- brak procesowego podejścia w realizacji potrzeb zakupowych. Nowy proces zakupowy oparty na analizie TCO wymaga dodatkowego nakładu czasu, potrzebnego choćby na zebranie stosownych danych i wykonanie analiz oraz prognoz;

- brak specjalistycznej wiedzy oraz doświadczenia w zakresie prowadzenia samodzielnej analizy TCO. Większość przyszłych właścicieli pojazdów nie wie, że do skutecznego przeprowadzenia analizy TCO potrzebny jest komplet danych uwzględniający wiele parametrów kosztowych;

- brak dostępu do specjalistycznych programów eksperckich. W dzisiejszej rzeczywistości rynkowej dostęp do narzędzi ma nieliczna grupa ekspertów motoryzacyjnych, co znacznie ogranicza możliwość ich popularyzacji i wykorzystania w optymalizacji procesów zakupowych, w szczególności w stosunku do takiego dobra, jakim jest samochód.

Podsumowując, prawidłowe oszacowanie TCO jest procesem nie tylko złożonym, ale i wymagającym interdyscyplinarnej wiedzy (Skudlik 2013). Warto podkreślić, że w skład tej zmiennej wchodzi wiele czynników, które na wstępnym etapie planowania zakupu samochodu mogą być nie w pełni weryfikowalne, a nawet są bardzo trudne do oszacowania. Mimo to strategia zakupowa oparta na analizie TCO coraz częściej wykorzystywana jest na rynku motoryzacyjnym w krajach Unii Europejskiej, gdzie świadomość użytkowników pojazdów i dealerów samochodów z roku na rok jest coraz większa.

\section{PARAMETR TOTAL COST OF OWNERSHIP JAKO NARZĘDZIE SŁUŻĄCE OPTYMALIZACJI PROCESU ZAKUPOWEGO - WYMIAR EKONOMICZNY}

Złożoność badanej problematyki, ustawiczna gra popytu i podaży samochodów oraz ciągłe zmiany strategii zakupowej na polskim rynku motoryzacyjnym wymagały od autora podejścia eksperymentalnego. Dlatego w celu ukazania istotnych zależności posłużono się z góry przyjętymi wzorcami zachowań. Tym samym przedmiotem dalszych rozważań będzie nie analiza procentowa poszczególnych kosztów składających się na całkowity koszt użytkowania pojazdu, a wyłącznie prezentacja i eksploracja uśrednionych całkowitych kosztów użytkowania poszczególnych modeli pojazdów z danego segmentu rynkowego. Ponadto na potrzeby niniejszych symulacji przyjęto w uproszczeniu, że analiza całkowitych kosztów użytkowania dotyczyć będzie 36-miesięcznego okresu użytkowania pojazdu, a nie całego procesu eksploatacji i związanych z tym kosztów, które - jak wiadomo na podstawie dostępnych badań poszczególnych modeli i pojazdów - w dłużej perspektywie stają się nieproporcjonalne (Al-Alawi 2013).

Na samym wstępie, w celu zachowania poprawności logicznej i wartości metodologicznej badań, przyjęto, że: 
- badaniami będzie objętych 5 pojazdów osobowych z segmentu aut kompaktowych, czyli z umownego zbioru, do którego należą samochody o określonych cechach lub przeznaczeniu. Wyselekcjonowane pojazdy były popularne wśród klientów, co oznacza największą liczbę sprzedanych egzemplarzy w roku 2016 na polskim rynku (Sprzedaż samochodów 2016);

- analiza całkowitych kosztów użytkowania pojazdu obejmować będzie dwa zasadnicze parametry - oszacowanie wartości rezydualnej pojazdu oraz oszacowanie kosztów jego użytkowania;

- koszty użytkowania będą dotyczyć takich kategorii, jak: ubezpieczenie pakietowe, czyli ubezpieczenia odpowiedzialności cywilnej i autocasco, koszty zużycia paliwa (cykl mieszany), opony, serwis (czyli koszt przeglądu pojazdu), eksploatacja (czyli koszy części eksploatacyjnych) i rejestracja pojazdu;

- do oszacowania wartości rezydualnych pojazdu posłuży specjalistyczny program ekspercki firmy Eurotax TCO, wspierając eksperyment numeryczny metodą prognozowania; obecnie jest to jedyny program do szacowania wartości rezydualnych samochodów osobowych w Polsce (Instrukcja 2017);

- do celów porównawczych w każdym przypadku ma służyć średnia wartość nowych pojazdów z poszczególnych segmentów rynkowych, określonych w programie eksperckim Eurotax na lipiec 2017 roku;

- we wszystkich symulacjach wszystkie wyselekcjonowane pojazdy mają mieć ten sam przebieg kilometrowy, a ich wyposażenie oraz stan techniczny mają być zbliżone.

$\mathrm{Na}$ potrzeby analizy oraz dla uzyskania potrzebnych danych wyniki eksperymentu numerycznego zaprezentowano $w$ tab. 1 i na ryc. 1.

Tabela1. Analiza TCO wybranych modeli z segmentu aut kompaktowych

\begin{tabular}{|c|c|c|c|c|c|}
\hline Marka & Opel & $\mathrm{KIA}$ & Volkswagen & Toyota & Skoda \\
\hline Model & $\begin{array}{c}\text { Astra } 1.4 \mathrm{~T} \mathrm{~S} / \mathrm{S} \\
\text { Enjoy }\end{array}$ & Ceed $1.4 \mathrm{M}$ & $\begin{array}{l}\text { GOLF 1,4 TSI } \\
\text { Comfortime }\end{array}$ & $\begin{array}{l}\text { Auris } 1,4 \\
\text { Premium }\end{array}$ & $\begin{array}{c}\text { Octavia 1,4 TSI } \\
\text { Ambition }\end{array}$ \\
\hline Moc $[\mathrm{kw} / \mathrm{km}]$ & $92 / 125$ & $92 / 135$ & $92 / 125$ & $97 / 132$ & $110 / 150$ \\
\hline $\begin{array}{l}\text { Okres [mies.] / } \\
\text { / całkowity przebieg } \\
{[\mathrm{km}]}\end{array}$ & $36 / 90000$ & $36 / 90000$ & $36 / 90000$ & $36 / 90000$ & $36 / 90000$ \\
\hline Cena zakupu [PLN] & 70500 & 64541 & 78130 & 71900 & 79151 \\
\hline $\begin{array}{l}\text { TCO - całkowity } \\
\text { koszt użytkowania } \\
\text { brutto [PLN] }\end{array}$ & 71912 & $\begin{array}{r}72265 / \\
+352\end{array}$ & $\begin{array}{r}75809 / \\
+3896\end{array}$ & $\begin{array}{r}76837 / \\
+4924\end{array}$ & $\begin{array}{r}77108 / \\
5195\end{array}$ \\
\hline $\begin{array}{l}\text { Utrata wartości } \\
\text { pojazdu [PLN] }\end{array}$ & 31265 & 30123 & 34298 & 31490 & 35782 \\
\hline $\begin{array}{l}\text { Koszt użytkowania } \\
{[P L N]}\end{array}$ & 40647 & 42142 & 41511 & 45347 & 41326 \\
\hline Rejestracja [PLN] & 198 & 198 & 198 & 198 & 198 \\
\hline $\begin{array}{l}\text { Ubezpieczenie } \\
\text { pakietowe [PLN] }\end{array}$ & 7731 & 7271 & 8279 & 7877 & 8361 \\
\hline $\begin{array}{l}\text { Paliwo w cyklu } \\
\text { mieszanym [PLN] }\end{array}$ & 20701 & 23542 & 21107 & 23948 & 20701 \\
\hline $\begin{array}{l}\text { Opony standardowe } \\
{[\mathrm{PLN}]}\end{array}$ & 5993 & 4491 & 6082 & 5994 & 6082 \\
\hline Serwis [PLN] & 2241 & 2647 & 2447 & 3800 & 2439 \\
\hline Eksploatacja [PLN] & 3782 & 3994 & 3398 & 3530 & 3544 \\
\hline
\end{tabular}




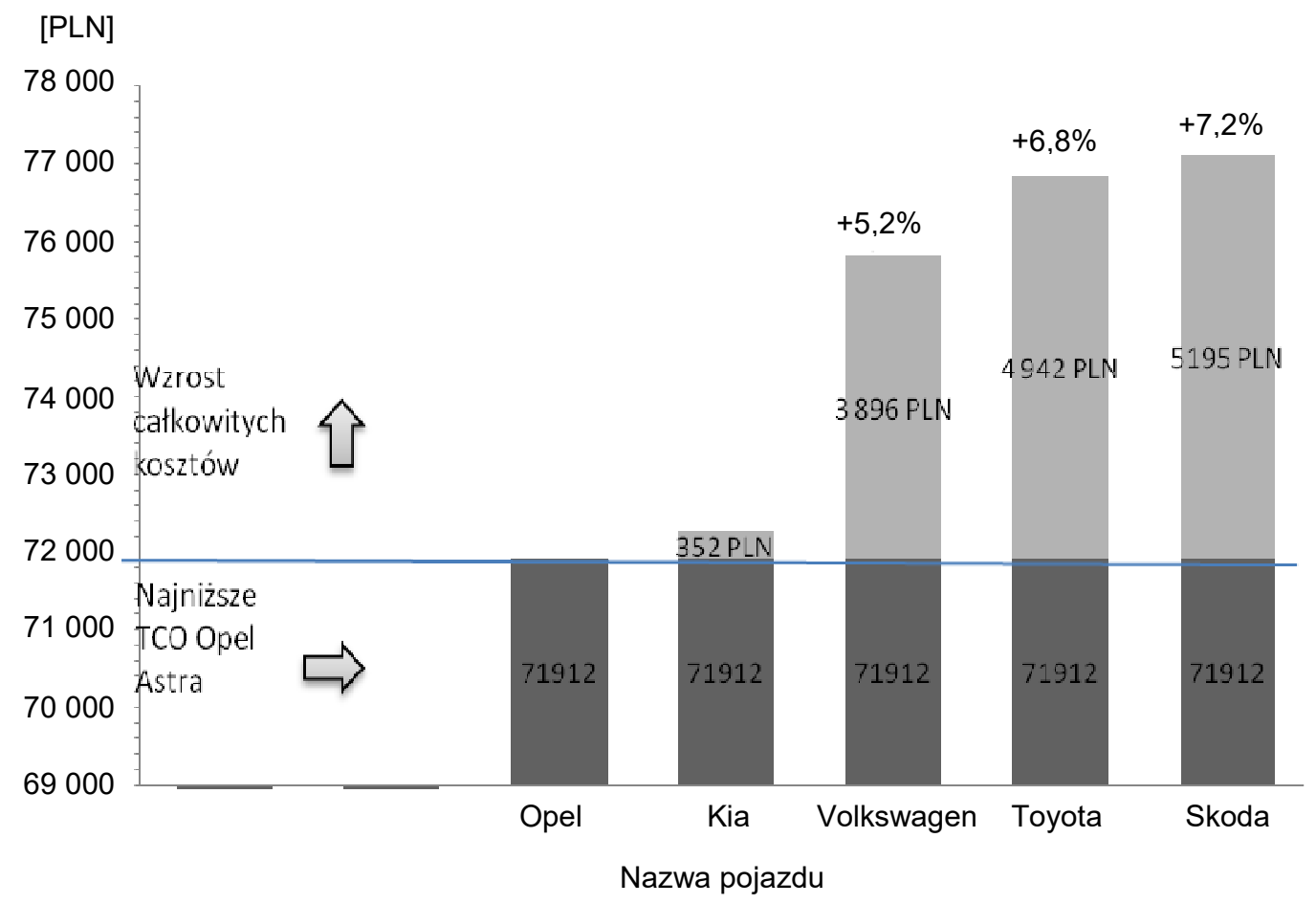

Ryc. 1. Analiza wzrostu całkowitych kosztów posiadania wybranych modeli z segmentu aut kompaktowych

Analiza danych z tab. 1 wskazuje na znaczne zróżnicowanie w kształtowaniu się całkowitych kosztów użytkowania, w zależności od danej marki pojazdu. Pozwala to na stwierdzenie, że we wszystkich analizowanych przypadkach po 36-miesięcznym okresie eksploatacji całkowite koszty użytkowania są wyższe od kwoty nabycia pojazdu. Ponadto, porównując poszczególne koszty, stwierdzono, że przewidywana utrata wartości stanowi największą część TCO i w przypadku poszczególnych modeli waha się od $40 \%$ do $55 \%$. Analiza danych pozwala także na stwierdzenie, że niższa cena zakupu nie musi oznaczać niższych kosztów użytkowania. Na przykład cena zakupu Opla Astry jest wyższa niż cena zakupu Kia Creed, ale całkowite koszty Opla Astry po 3-letnim okresie eksploatacji są niższe o 352 PLN.

Analizując wyniki badań zaprezentowane na ryc. 1 (dotyczące analizy wzrostu całkowitych kosztów posiadania pojazdu w przypadku 36-miesięcznego okresu użytkowania), stwierdzono, że najniższe koszty całkowitego użytkowania dotyczą pojazdu Opel Astra; wynoszą one 71912 PLN. Natomiast najwyższe koszty stwierdzono w przypadku Skody Octavii; wynoszą one 77108 PLN (kwota ta jest wyższa o 7,2\%, czyli o 5195 PLN niż w przypadku Opla Astry).

\section{WNIOSKI}

Obserwacje polskiego rynku motoryzacyjnego wskazują wyraźnie, że decyzja zakupowa oparta na wykorzystaniu TCO wciąż jest zjawiskiem incydentalnym. Wpływ na to ma między innymi brak specjalistycznej wiedzy i doświadczenia wynikające ze stosowania tego narzędzia. Ponadto w dzisiejszej rzeczywistości rynkowej dostęp do programów eksperckich 
ma nieliczna grupa ekspertów motoryzacyjnych, co znacznie ogranicza możliwość wykorzystania tego wskaźnika w tym konkretnym procesie. W większości przypadków są nimi rzeczoznawcy samochodowi albo przedstawiciele sektora CFM, którzy oferują usługi zarządzania flotami pojazdów w ramach outsourcingu. Nie zmienia to jednak faktu, że wykorzystanie TCO w procesie decyzyjnym może przynieść znaczne korzyści ekonomiczne zarówno dla użytkownika prywatnego, jak i użytkownika floty. Podsumowując, autor nie popełnił błędu myślowego, jeżeli założył, że TCO, czyli całkowite koszty posiadania pojazdu, można uznać także za obiektywny i zarazem nowatorski wskaźnik optymalizacji procesu zakupu samochodów osobowych dla wszystkich segmentów rynkowych w Polsce.

Natomiast analizując przedstawione sumarycznie wyniki symulacji całkowitych kosztów posiadania pojazdów z segmentu aut kompaktowych, stwierdzono:

- znaczne zróżnicowanie w kształtowaniu się całkowitych kosztów użytkowania, w zależności od danej marki pojazdu;

- po 36-miesięcznym okresie użytkowania całkowite koszty użytkowania wyższe od ceny nabycia pojazdu;

- przewidywaną utratę wartości, która stanowi największą ich część i w przypadku poszczególnych modeli waha się w przedziale od $40 \%$ do $55 \%$;

- najniższe koszty całkowitego użytkowania pojazdu w przypadku Opla Astry, natomiast najwyższe - Skody Octavii (wzrost o 7,2\%).

Podjęta przez autora próba zwrócenia uwagi na istotę parametru TCO, jako narzędzia służącego optymalizacji procesów zakupowych samochodów osobowych z wybranego segmentu rynkowego, sygnalizuje jedynie złożoność badanej problematyki, jaką jest kształtowanie się strategii zakupowych na rynku samochodów osobowych w Polsce. Zatem zrozumienie determinantów ekonomicznych i pozaekonomicznych, kształtujących popyt i podaż na tym zmiennym i osobliwym rynku, wymaga nieprzerwanych analiz i badań.

\section{PIŚMIENNICTWO}

Al-Alawi B., Bradley T. 2013. Total cost of ownership, payback, and consumer preference modeling of plug-in hybrid electric vehicles. App. Energy 103, 488-500.

Burnewicz J. 2005. Sektor samochodowy Unii Europejskiej. Warszawa, WKŁ, 45-46.

Ellram L. 1995. Total cost of ownership - An analysis approach for purchasing. Inter. J. Phys. Distr. Log. Manag. 25(8), 4-23.

Daum J.H. 2011. Value based management for the new economy. Materiały firmy SAP AG,

Instrukcja programu EUROTAX TCO. 2017. Warszawa, Eurotax Polska, 5-7.

Kożlak A. 2010. Ekonomika transportu. Teoria a praktyka gospodarcza. Gdańsk, Wydaw. UGdań., 17-19.

Podstawy marketingu. 2012. Red. A. Czubała. Warszawa, PWE, 120-122.

Rogowski W. 2004. Rachunek efektywności przedsięwzięć inwestycyjnych. Kraków, Oficyna Ekonomiczna, 30-31.

Rozporządzenie Rady Ministrów z dnia 8 października 2010 r. w sprawie wyłączenia określonych porozumień wertykalnych $w$ sektorze pojazdów samochodowych spod zakazu porozumień ograniczających konkurencję. DzU z 2010 r., nr 198, poz. 1315.

Skudlik M. 2013. Podstawy finansów i rachunkowości podręcznik dla menadżerów. Gliwice, Wydaw. HELION, 15-16. 
Soltysiak M. 2015 Preferencje zakupowe kobiet na rynku pojazdów samochodowych, w: Systemy i środki transportu samochodowego. Wybrane zagadnienia. Red. K. Lejda. Rzeszów, Oficyna Wydaw. PRzesz., 45.

Sprzedaż samochodów osobowych i dostawczych w roku 2016 r. 2016. Warszawa, SAMAR, 7-8.

Schwan R. 2009. Das Konzept des Total Cost of Ownership (TCO) in der IT GRIN Verlag, 66-69.

Trömner M. 2014. Decrease in market value of a motor vehicle. Eur. Sci. J. Spec. Edit. 1, 98-99.

Womack J., Jones D., Roos D. 2014. The machine that changed the world. New York, Rawson Macmillan, 8.

Streszczenie. W artykule podjęto próbę zwrócenia uwagi na istotę wykorzystania wskaźnika TCO, czyli całkowitego kosztu posiadania, jako narzędzia służącego optymalizacji procesów zakupowych na przykładzie wyselekcjonowanych samochodów osobowych z wybranego segmentu rynkowego. Dla celów empirycznych posłużono się studium przypadku - eksperymentem numerycznym polegającym na wykorzystaniu analizy TCO do optymalizacji procesu zakupowego danego pojazdu z konkretnego segmentu rynkowego. Całość rozważań uzupełniono o omówienie istoty parametru TCO w procesie określania całkowitych kosztów posiadania pojazdu. Zamierzeniem artykułu jest zasygnalizowanie pożądanych perspektywicznych kierunków zmian w procesach wykorzystania TCO w zakresie definiowania przyszłej strategii zakupowej zarówno w przypadku użytkowników prywatnych, jak i właścicieli flot pojazdów w Polsce. 